\title{
The functional role of long non-coding RNAs and epigenetics
}

Jinneng Cao

\begin{abstract}
Long non-coding RNAs (IncRNAs) are non-protein coding transcripts longer than 200 nucleotides. The post-transcriptional regulation is influenced by these IncRNAs by interfering with the microRNA pathways, involving in diverse cellular processes. The regulation of gene expression by IncRNAs at the epigenetic level, transcriptional and post-transcriptional level have been well known and widely studied. Recent recognition that IncRNAs make effects in many biological and pathological processes such as stem cell pluripotency, neurogenesis, oncogenesis and etc. This review will focus on the functional roles of IncRNAs in epigenetics and related research progress will be summarized.
\end{abstract}

Keywords: IncRNAs, Epigenetics, Transcriptional repression, Chromatin

\section{Introduction}

Messenger RNA (mRNA) is the RNA that carries information from DNA to the ribosome for protein synthesis. And yet, many RNAs do not code for proteins in eukaryotes. There are RNAs that lack an apparent open reading frame (ORF) of $300 \mathrm{nt}$ or longer. They do not encode a protein product thus classified as putative noncoding RNAs [1-3]. Long non-coding RNAs (lncRNAs) are molecules longer than $2 \mathrm{~kb}$ in length with a coding potential of less than 100 amino acids, or non-protein coding transcripts with the length of longer than 200 nucleotides (nt) [1,4-6]. For this definition, it somewhat arbitrary could not distinguish lncRNAs from small regulatory RNAs. Now, there have been identified far greater amounts of lncRNAs than protein coding genes [7-9]. A majority of annotated eukaryotic protein-coding ORFs were characterized with high level of phylogenetic diversity and the conservation. And the level of its conservation and the rate of synonymous to no synonymous substitutions were applied as additional criteria. It also applied for distinguishing the protein-coding transcripts containing bona fide functional ORFs from non-coding transcripts among novel RNAs [1-3]. As we know, there is an underlying dogma of molecular biology that the purpose of RNA is to direct the assembly of proteins from amino acids. However, a few exceptions to this paradigm were explored

Correspondence: jinnengcao@126.com

Department of respiratory medicine, Fuyong People's Hospital, Baoan District, Shenzhen 518103, Guangdong, People's Republic of China (such as ribosomal RNA and transfer RNA), which were functional RNA macromolecules that did not code for protein [10].

It has been reported that about $20 \%$ of transcription progress across the human genome would be associated with protein-coding genes [11]. The fact indicates that lncRNAs is at least four-times longer than coding RNA sequences [5]. However, it may be large-scale complementary DNA (cDNA) sequencing projects to reveal the complexity of transcription, such as FANTOM (Functional Annotation of Mammalian cDNA) [12].

RNA is an information encoding molecule with high flexibility and high-fidelity. It has also been characterized with easy activation, modification, transportation, and degrasion. Thus, RNA is considered as an integrative character of both the digital lexicon of DNA and the analog language of proteins. It is also a dynamic participant of DNA and protein molecules in performing cellular activities.

According to taxonomic, non-coding RNAs (ncRNAs) are composite of the familial "housekeeping" RNAs and regulatory RNAs in recent intensive studies. There are many different sizes of NcRNAs and for this reason they have been divided into small and long classes: small ncRNAs (sncRNA) being less than 200 nt and lncRNA greater than $200 \mathrm{nt}$ to over $100 \mathrm{~kb}$ in length [13]. The current cut-off has been arbitrary and corresponds to specific biochemical protocols. Most categories of small 
infrastructural or regulatory RNAs have been excluded (tRNAs, snRNAs, miRNAs, siRNAs, piRNAs, tiRNAs, spliRNAs, sdRNAs and others) (Figure 1) [10].

It is predicted that there are thousands of IncRNAs in the mammalian transcriptome [2,14-17]. No strict minimal size is required for classifying a noncoding transcript as a "long" non-coding RNA and there were many lncRNAs with thousands of nucleotides [18]. There are no clear-cut, uniformly available criteria for determining a non-coding character of an RNA $[2,19,20]$. The widely accepted method for distinguishing protein-coding and non-coding RNAs among novel transcripts has analyzed the ORFs in each transcript as a primary criterion [21-24].

Epigenetics associated with a gene activity state that may be stable over long periods of time, persist through many cell divisions, or even be inherited through several generations and all without any variations to the primary DNA sequence [25-27]. What is the relationship of lncRNAs and epigenetics? In this review, the recent studies will be included and we have tried to demonstrate the function of lncRNAs and its influences on epigenetics.

\section{The function of IncRNAs}

LncRNAs were considered as non-functional junk initially. And now, their presence and significance have still being debated [28-30]. It is now apparently observed that many lncRNAs are the key regulators of transcriptional and translational output and therefore make effects on cell identify and function (Figure 2) [17,31-33]. However, different from general mRNAs exported to the cytoplasm for translation, many lncRNAs are now known to be restrained in various sub-nuclear compartments $[3,34,35]$, which suggesting that such RNAs may have a potential function in the compartment where they are located.
Studies have shown that lncRNAs play critical regulatory roles in diverse cellular processes such as chromatin remodeling, transcription, post-transcriptional processing and intracellular trafficking [16,19,31,36-40] (Figure 3). LncRNAs could be a highly abundant, rapidly evolving class of cellular factors with a wide range of cellular functions $[2,19,36,41]$.

\section{Imprinting}

Imprinting has been a significant process in identifying special nucleic acid and protein, such as DNA methylation and histone modification. LncRNAs have been found to participate in imprinting processes. It means lncRNAs influence the monoallelic expression of a gene according to its parents of origin. More than 200 lncRNAs were found to participate in imprinting processes. Depending on their parental origins, differentially methylated regions unmethylated DNA imprinting control regions (ICRs), resulting in specific expression of nearby lncRNAs and suppressing neighboring genes in cis [42].

The H19 IncRNA-MBD1 complex could interact with histone lysine methyltransferases. Therefore, it could work by bringing repressive histone marks on the differentially methylated regions of the three direct targets of the H19 gene [43].

Airn and Kcnq1ot1/LIT1 (Kcnq1 opposite transcript 1, or long QT intronic transcript 1) are examples of lncRNAs that cause suppression of paternally inherited genes. In particular, Kcnq1ot1/LIT1 is involved in the repression of several protein-coding genes in cis by interacting with repressive chromatin modifying complexes $[44,45]$. Kcnq1ot1/LIT1 is an imprinted region contains at least eight genes that are expressed exclusively or preferentially from the maternal allele [46]. Kcnq1ot1/LIT1 acts as an organizer on a tissue/lineage-specific nuclear domain,

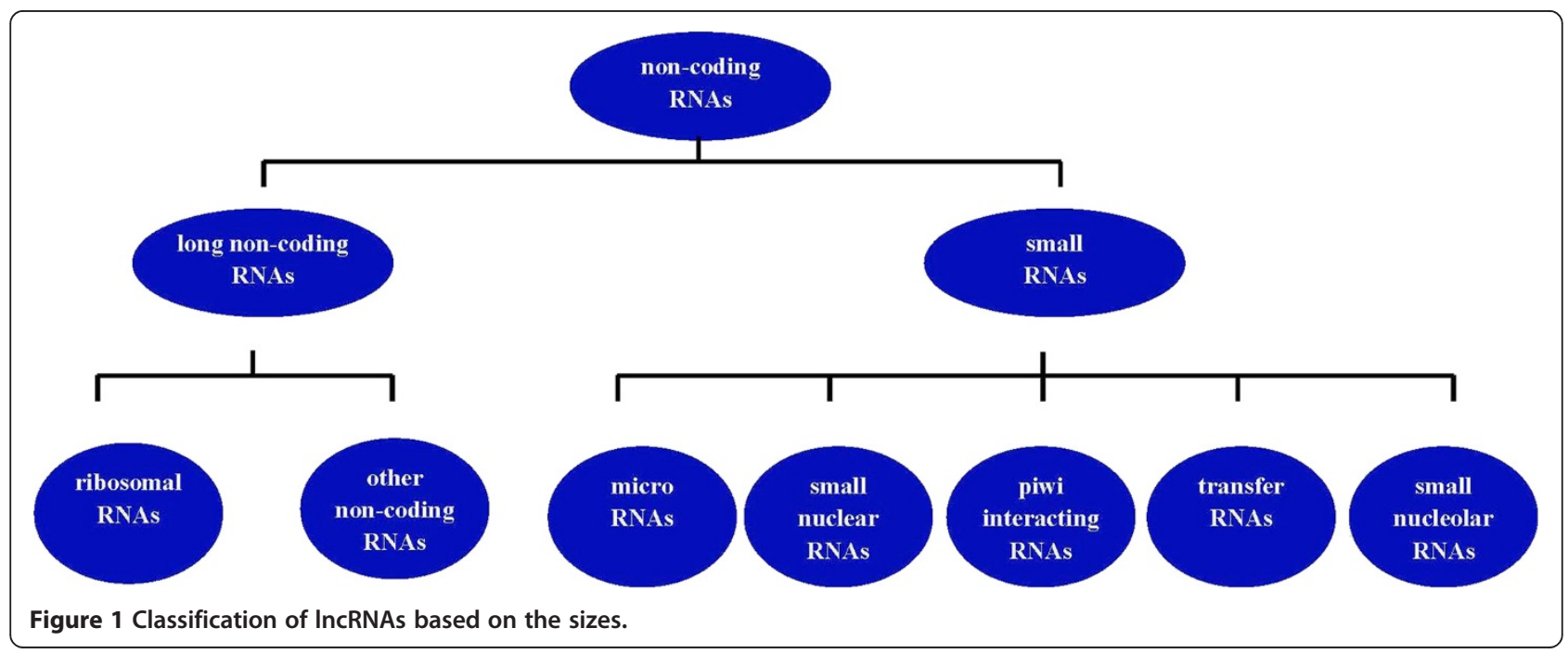




\section{A}

\section{Transcription activation}

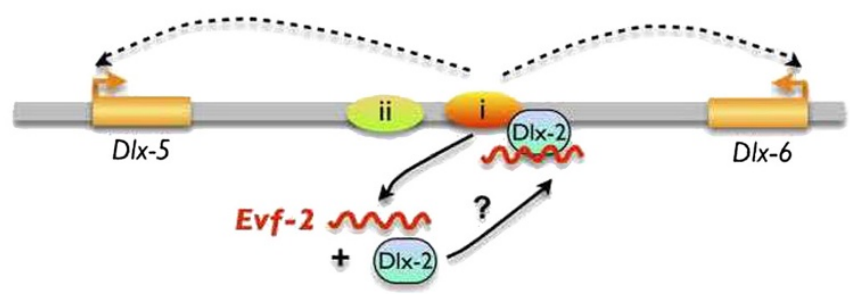

B

\section{Transcription suppression}

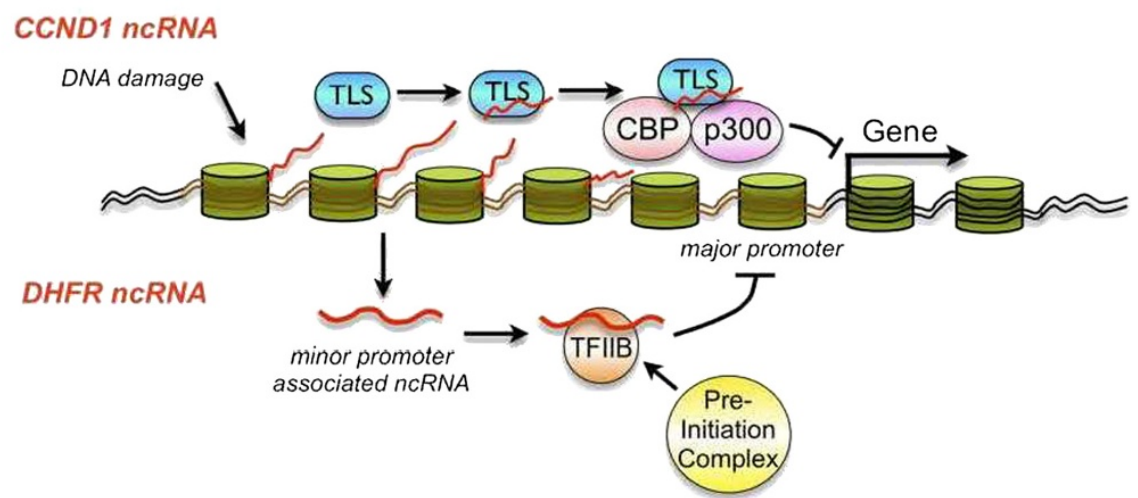

Figure 2 Long non-coding RNA-mediated transcription regulation. A. Transcription activation by IncRNA. In this example, Evf-2 is transcribed from an ultra-conserved enhancer and forms a stable complex with Dlx-2, which in turn activates Dlx-2 as a transcriptional enhancer. B. Transcription suppression by IncRNA. Top: in response to DNA damage, IncRNAs are transcribed from the 5'-upstream region of the CCND1 gene and recruit the RNA-binding protein TLS to modulate CBP and p300 to inhibit CCND1 transcription. Bottom: LncRNA transcribed from the upstream of the minor promoter of DHFR gene competes with transcription factors to inhibit the major promoter transcription in quiescent cells.

involving in epigenetic silencing of the Kcnq1 imprinting control region [46-49].

\section{Developmental regulation}

LncRNAs have played crucial roles in controlling gene expression during both developmental and differentiation processes. Furthermore, the number of IncRNA species will be higher in genomes of developmentally complex organisms. It highlights the significance of RNAbased levels of control in the evolution of multi-cellular organisms [50]. Expression of IncRNAs is dynamically regulated during male germline development. On the contrary, lncRNAs may function to regulate gene expression at both transcriptional and posttranscriptional levels based on both genetic and epigenetic mechanisms [51].

MEG3 (Gtl2) was a lncRNAs in human with the length of about $1.6 \mathrm{~kb}$. There are a number of splice isoforms in MEG3 and it retains introns creating longer transcripts
$[52,53]$. Recent studies have shown that Meg3 splicing isoform was silenced and in pituitary tumor, cancer cell growth would be inhibited by its ectopic expression. All these results suggested that Meg3 RNA acted as a growth suppressor [54]. Furthermore, MEG3 expression is not only associated with tumor grade, but also suppressing DNA synthesis and stimulating p53-mediated trans-activation in meningiomas cell lines [55]. Meg3 may play vital antitumor effects in tongue squamous cell carcinoma pathogenesis and represent potential prognostic biomarkers for stratification of patients with tongue squamous cell carcinoma [56].

\section{Diseases associated induction/derivation}

More and more evidences have proved that lncRNAs play critical roles in various biological processes. The mutations and dys-regulations of these lncRNAs contribute to the development of many complex diseases, 

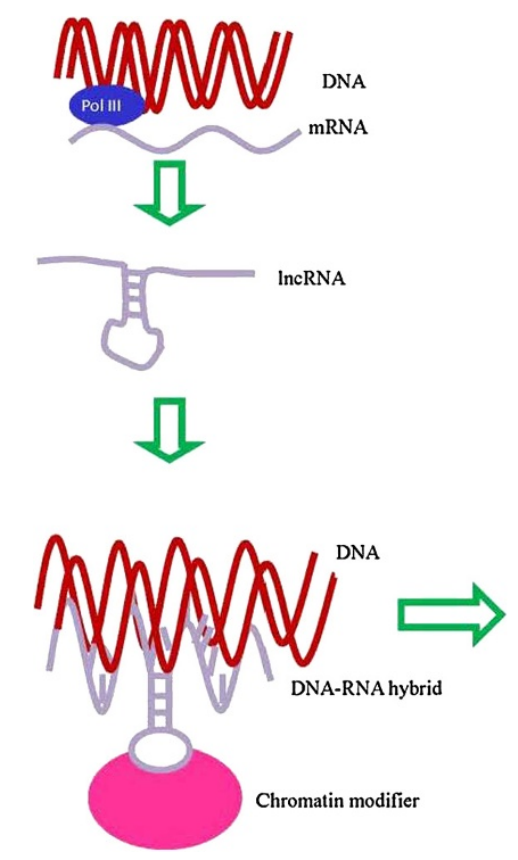

Figure 3 Possible IncRNA targeting mechanisms. Based on these potential mechanism, IncRNAs may play critical regulatory roles in diverse cellular processes such as chromatin remodeling, transcription, post-transcriptional processing and intracellular trafficking [16,19,31,36-40].

such as virus infection and carcinogenesis. Beta2.7 is the popular one being studied in virus infection. Generally, beta2.7 specifically binds and prevents the re-localization of essential complex I subunit GRIM-19 (gene associated with retinoid/interferon-induced mortality-19). In response to apoptotic stimuli, beta2.7 is responsible for stabilizing the mitochondrial membrane potential and mitochondrial ATP production. It also prevents metabolic dys-function, which will be essential for completing the virus' life cycle $[57,58]$. The reactive oxygen species production will be reduced by the over-expression of beta2.7 RNA, thus the apoptosis could be inhibited $[59,60]$. LncRNAs have been strongly associated with cancer [61]. The expression of LncRNA PRINS (Psoriasis susceptibility-related RNA Gene Induced by Stress) will be in psoriatic epidermis and it will also be regulated by the proliferation and differentiation state of keratinocytes [62-64]. In keratinocytes, the expression of G1P3 is an anti-apoptotic protein with high expression in psoriasis and it will be regulated by lncRNA PRINS [65].

LncRNAPCAT-1, a target gene of polycomb repressive complex 2, has been implicated in disease progression by promoting cell proliferation [66]. The up-regulation of ANRIL (antisense non-coding RNA in the INK4 locus) is required for the expression of the tumor suppressors INK4a/p16 and INK4b/p15 in prostate cancer [67-69]. HOTAIR up-regulation is associated with poor prognosis in breast cancer, liver, colorectal, gastrointestinal and pancreatic cancers. Meanwhile, it also probably contributes to promote the tumor invasiveness and metastasis
[70-75]. In human melanomas, approximately 50 genes have been partly regulated by hyper-methylation of $\mathrm{CpG}$ islands in their regulatory regions [76].

Compared with DNA or protein, RNA molecules are considered to be more efficiently couple bioenergetic requirements with information storage and processing [77]. Therefore, the advent of RNA based networks is thought to be responsible for fueling the explosive evolutionary innovations, which may characterize the human brain form and function $[41,78,79]$. The brain is a conspicuous consumer of energy resources. It is also a major consequence of cerebral ischemia for energy metabolism and exhaustion of adenosine triphosphate [80]. Brain development and function are tightly regulated by epigenetic mechanisms by gene expression modulation in response to intrinsic and extrinsic signals $[81,82]$. The lncRNAs are also dynamically expressed during pluripotency and differentiation in neural or glial cells $[83,84]$. The knock-down of four lncRNAs has been associated with neuronal differentiation. The function of these mentioned IncRNAs were mainly physically interacted with SOX2, PRC2 complex component, REST and SUZ12. The cellular differentiation fate will be altered from a neurogenic to a gliogenic program. The results suggested the functional role of the lncRNAs in neural cell fate specification [84-87].

\section{The versatile function of IncRNAs}

There are many different functions of lncRNA has been explored in latest few years. Besides of transcription 
regulation, there are also several versatile lncRNAs that have been evidenced, such as Kcnq1ot1, Airn, Xist and HOTAIR. Their function have mainly focused on regulating transcription of multiple target genes through epigenetic modifications [46,88-90]. For the insulin like growth factor 2 receptor (Igf2r) imprinted cluster, located on mouse chromosome 17, the expression of paternalspecific non-coding transcript antisense Igf2r RNA (Airn, $108 \mathrm{~kb}$ ), is required for the silencing of three genes on the paternal allele. These genes have spread over a large genomic region spanning $400 \mathrm{~kb}$ [91]. On the mouse $\mathrm{X}$-chromosome, expression of X-inactive specific transcript (Xist) of IncRNA from the designated inactive $\mathrm{X}$-chromosome is essential for the silencing of inactive $\mathrm{X}$-chromosome $[87,92-94]$. Some genes on the Homeobox D (HOXD) cluster are located over a $40 \mathrm{~kb}$ genomic region on human chromosome 2 . These genes will be silenced by lncRNA HOTAIR, which is originated from the HOXC cluster on chromosome 12 [95]. On mouse chromosome 7 , the potassium voltage-gated channel subfamily Q member 1 (Kcnq1) imprinted cluster spreads over a $1 \mathrm{Mb}$ genomic region in embryos. Multiple genes are contained and it will be silenced on the paternal allele by the un-spliced lncRNA Kcnq1 overlapping transcript 1 (Kcnq1ot1, $91 \mathrm{~kb}$ ) in cis. While, some lncRNAs, transcribed by RNA polymerase II, are able to recruit transcriptional repressive complexes including PcGs and G9a to silence specific genomic regions, both in cis (top) and in trans (bottom) [31,96,97] (Figure 4).

Spliced lncRNAs, compared with such un-spliced as single exon transcripts, intergenic and cis-antisense RNAs are more stable than those derived from introns [98]. The sub-cellular localization analysis indicates the location of lncRNAs is widespread in cell, with nuclear-localized IncRNAs more likely to be unstable [99].

\section{LncRNAs and epigenetics}

Epigenetics is applied to describe the study of heritable variations in gene activity which is independent of DNA sequence variations in genetics. It is generally applied to refer to epigenetic modifications on the genetic material of one cell. Epigenetics is analogous to genomics and proteomics and it is the study focusing on genome and proteome of one cell [100]. Epigenetic modifications are reversible modifications on the DNA of one cell or histones that may affect gene expression without altering the DNA sequence [100].

\section{LncRNAs linked with epigenetics by DNA methylation}

Chromatin is the combination of DNA and proteins that collectively make up the contents of cell nucleus [101,102]. Chromatin is in charge of DNA packaging, gene expression and DNA replication [103,104]. The mechanism of epigenomic control is generally considered at the level of chromatin [105-107]. Histones proteins can be chemically modified by as the process such as acetylation, methylation, sumoylation and ubiquitylation. The processes will result in structural variations in chromatin and the access of DNA will be allowed [108-112].

Recent findings reveal that lncRNAs are implicated in serial steps of cancer development [113]. These lncRNAs interact with DNA, RNA, protein molecules and/or their combinations. It acts as an essential regulator in chromatin organization, transcriptional and post-transcriptional regulation. Their mis-expression confers the cancer cell capacities for tumor initiation, growth, and metastasis. There is also a review demonstrating the roles of IncRNAs in cancer diagnosis and therapy. It reported expression profiles were different for numerous IncRNA in urothelial cancer [114]. The phenotype-specific expression and a potential mechanistic target were studied and it demonstrated that the

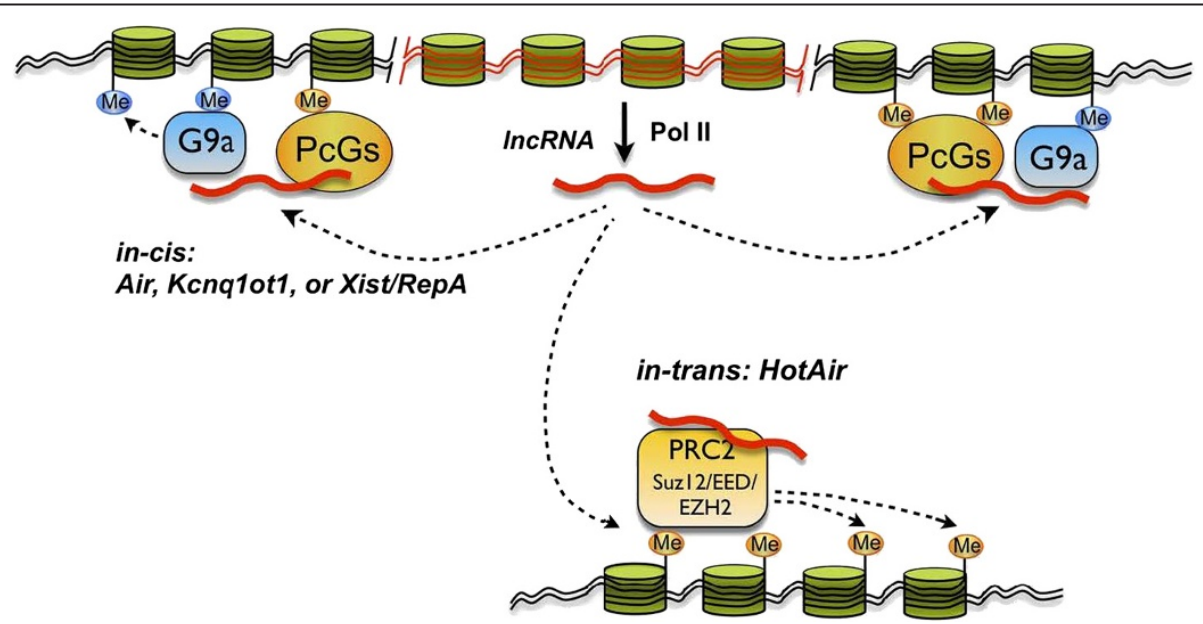

Figure 4 Long non-coding RNA-mediated chromatin remodeling. The IncRNAs, transcribed by RNA polymerase II could recruit transcriptional repressive complexes including PcGs and G9a to silence specific genomic regions, both in cis (top) and in trans (bottom) [31,96,97]. 
IncRNAs may be prognostic biomarkers for this cancer. The LncRNAs such as up-regulation of HOTAIR could be associated with poor prognosis in breast cancer, liver, colorectal, gastrointestinal and pancreatic cancers. Meanwhile, it also probably contributes to promote the tumor invasiveness and metastasis [70-75].

There are CpG islands in the upstream region of the miR-375 gene and aberrant DNA methylation in this gene can be observed in specific melanoma stage $[115,116]$. Histone modification of DNA methylation is one vital epigenetic mechanism to regulate the expression of genes [117]. DNA methylation and histone modifications are epigenetic mechanisms leading to the deregulation of lncRNAs expression in cancers [118]. Epigenetic up-regulation of lncRNAs at 13q14.3 in leukemia is linked to the down regulation of Cis. It is a gene cluster that targets in NF-kB [119]. Normal melanocytes, keratinocytes and cell lines derived from stage one melanoma were minimal methylated at this locus [120-122]. Whereas, the islands from cancer cells derived from stage three or more advanced metastatic melanoma samples were hyper-methylated [123,124]. The tumor suppressor lncRNAs will be down-regulated or silenced by DNA methylation. And hence consequent up-regulation of oncogens would be involved in carcinogenesis [125]. Hypermethylated lncRNAs were re-expressed by demethylation treatment with DNA methylation transferase (DNMT) inhibitor, 5-azadC, within 24-96 h [126]. The expression of hyper-methylated lncRNAs would be further enhanced by treatment in combination with histone deacetylase (HDAC) inhibitor such as 4-phenylbutyric acid or trichostatin [127]. The fact indicated a collaborative role between DNA methylation and histone modifications during the silencing effect of tumor suppressive lncRNAs [128]. A few DNA methyltransferase proteins including Dnmt3a and Dnmt3b [129], as well as methyl-DNA-binding domain proteins (MBDs), are able to form DNA-protein complexes [130].

As for human melanomas, abnormal methylation of the tumor suppressor RASSF1 is a hallmark of many cancers including uveal and metastatic melanoma [131,132]. DNA methylation was considered as predictors of recurrence in non muscle invasive bladder cancer: an MS-MLPA approach $[133,134]$.

Considering the complex origin of melanoma and the existence of heterogeneous subtypes, it is considered that the presence of a single biomarker would not be sufficient to make an informed diagnostic decision [135]. The high affinity RNA-binding activity of MBD proteins was recently characterized and it seemed to be different from the methyl CpG DNA binding domain protein. It was hypothesized that DNMTs and MBD proteins may allow RNA molecules to participate in DNA methylationmediated chromatin regulation [136].

Chromatin modifications appear to be correlated with CpG island methylation, in which methylation is repeatedly exhibited in tracts of DNA sequence at the fifth carbon atom of cytosines. Cytosine methylation is the only known endogenous modification of DNA in mammals and it occurs through DNA methyltransferase-mediated methylation [137].

There is one of the best understood mechanisms behind epigenetics. It involved methylation of cytosine residues at specific positions in the DNA molecule $[138,139]$. It has well characterized the enzymes that have carried out the methylation reaction [140]. The mechanism is that the configuration of methylated positions is propagated through DNA replication [141]. The typical consequence of methylation in a genomic region is the repression of nearby genes [142].

\section{Epigenetic role for IncRNAs in gene regulation}

A novel mechanism of epigenetic repression of the RASSF1A tumor suppressor gene has involved antisense unspliced lncRNA. In this mechanism, the expression of the RASSF1 isoform has been selectively repressed by ANRASSF1, overlapping the antisense transcript in a location-specific manner [143].

During the latent infection of human cytomegalovirus (HCMV) in CD14 (+) and CD34 (+) cells, RNA4.9 interacts with components of the polycomb repression complex (PRC) as well as the MIE promoter region where the enrichment of the repressive H3K27me3 mark. It will also disclose the repression function of lncRNA on transcription [144].

Berghoff EG and his colleague have shown that Evf2 (Dlx6as) lncRNA antisense transcription, Evf2-dependent balanced recruitment of activator and repressor proteins enabled differentially transcriptional control of adjacent genes with shared DNA regulatory elements [145]. Researches from another lab indicated that the intronic long non-coding RNA ANRASSF1 recruited PRC2 to the RASSF1A promoter, reducing the expression of RASSF1A and increasing cell proliferation [146]. LncRNA loc285194 is a p53 transcription target; tumor cell growth is inhibited by ectopic expression of loc 285194 both in vitro and in vivo [147].

The lncRNA-LET has been reduced by hypoxia-induced histone deacetylase 3 by reducing the associated histone acetylation-mediated modulation of the lncRNA-LET promoter region. And the down-regulation of IncRNA-LET was found to be a key step in the stabilization of nuclear factor 90 protein. It leads to hypoxia-induced cancer cell invasion [148]. IncRNA-HEIH plays a key role in cell cycle arrest at stage $\mathrm{G}(0) / \mathrm{G}(1)$. In addition, it was associated with enhancer of zeste homolog 2 (EZH2) and also required for the repression of EZH2 target genes [149].

TNF $\alpha$ expression is regulated by the long non-coding RNA THRIL (TNF $\alpha$ and hnRNPL related immunoregulatory LincRNA: large intergenic non-coding RNAs) 
through its interaction with hnRNPL (heterogeneous nuclear ribonucleoprotein L) [150]. Both activation and repression of immune response genes would be mediated by lincRNA-Cox2 [151].

\section{Epigenetic role for IncRNAs in gene activation}

The dynamics of miRNA regulatory network mediated by RNA editing is implicated in stroke. LncRNAs-151 is found to be unregulated after middle cerebral artery occlusion. The immature form of lncRNAs-151 is subject to RNA editing that influences the primary lncRNAs processing into mature lncRNAs within the CNS [152]. Intriguingly, lncRNAs-151 is thought to target in various cell cycle regulators as well as protein tyrosine kinase 2 (focal adhesion kinase), which is a non-receptor tyrosine kinase involved in integrin and growth factor signaling pathways. The pathways aredifferentially regulated after middle cerebral artery occlusion and implicated in modulating neurite outgrowth, neuronal plasticity, and restoration of neural network integrity within the ischemic penumbra [153-155]. Furthermore, lncRNADQ786243 makes effects on regulating the expression of CREB and Foxp3, consequently with the regulation of $\mathrm{T}$ regulator cells in Crohn's disease [156].

\section{Enhancer-like activity of IncRNAs}

Enhancer-associated (elncRNA) and promoter-associated (plncRNA) elements play different roles in the chromatin status at intergenic lncRNAs transcription [157]. Expression of elncRNAs, but not plncRNAs, is associated with enhanced expression of neighboring protein-coding genes during erythropoiesis [157].

LncRNAs are dynamically expressed during erythropoiesis with epigenetic regulation. And they are targeted by key erythroid transcription factors such as GATA1, TAL1 and KLF1. After exploring 12 candidate lncRNAs, they were nuclear-localized, exhibiting complex developmental expression patterns. Depleting them severely impaired erythrocyte maturation, inhibiting cell size reduction and subsequent enucleation. IncRNA-EC7 is transcribed from an enhancer and is specifically needed for activation of the neighboring gene encoding BAND 3 [158].

Recently, researchers have identified a translational regulatory lncRNA (trlncRNA) through genome-wide computational analysis. Furthermore, they found trlncRNA was upregulated in paired clinical breast cancer primary and lymph-node metastasis samples. Tumor invasion and metastasis will be stimulated by its expression in vitro and in vivo, respectively. In addition to this, trlncRNA is involved in the down-regulation of the epithelial marker E-cadherin by suppressing the translation of its mRNA [159].

\section{The epigenetic influence on chromatin from IncRNAs}

Cellular reprogramming is known to accompany cell type-specific epigenetic alterations of the genome. It is the conversion of one specific cell type to another. Chromatin structure and dynamics can be influenced by epigenetic factors such as covalent histone modifications, histone variants, DNA methylation, ncRNAs and etc. Chromatin remodeling complex may play an important role in cell fate decision [160]. It has found that 28 lncRNAs are associated in cell invasiveness. It also represented the first key step for successful metastasis. Moreover, another ncRNA (HOTAIR long ncRNA) is able to promote cancer metastasis by inducing epigenetic variations in the chromatin state of cancer cells [161]. Many tumor suppressor genes were found to carry antisense transcripts [162]. For example, p15, a cyclindependent kinase inhibitor implicated in leukemia, possesses an antisense transcript and silencing its transcription in cis and in trans by inducing heterochromatin formation without changing DNA methylation in a Dicer-independent manner [163-166]. It is possible that these antisense transcripts directly bind and recruit chromatin-modifying complexes to their associated sense transcripts [167]. The role of non-coding RNAs in chromatin formation has also been observed in plants $[168,169]$. One study found that targeted 3 prime processing of a non-coding antisense transcript to the FLC gene (a major floral repressor gene), resulting in the recruitment of FLD. It is a homolog of the human histone demethylase LSD1, which targets H3K4me2 for demethyaltion [170]. Antisense mediated chromatin modifications appear to mostly operate in cis in contrast to lincRNAs which can operate both in cis and in trans [171,172].

The human body is composed of hundreds of distinct cell types. There is a specific position for each cell within the body and each cell performs a specific function. Since all the cells within a multi-cellular organism contain the same genome, the information that inducing cells to establish their identity is likely to be coded in their epigenome [173]. The epigenome is comprised of modifications of DNA (i.e., DNA methylation) and modifications of histone proteins at specific amino acid residues (e.g., acetylation, methylation, phosphorylation, etc.) [174]. Key regulators of the epigenome are chromatinmodifying complexes that can add or remove covalent modifications to chromatin $[175,176]$. The transcription factors can recognize and bind to specific DNA sequences. In contrast to transcription factors, the majority of chromatin-modifying complexes do not able to binding DNA [177]. A major gap in our understanding of epigenetic regulation for chromatin-modifying complexes is how these complexes are targeted to specific regions of the genome. Recent studies have recently shown that the Jumanji protein Jarid2 could recruit the polycomb repressive complex (PRC) 2 to its target sites in 
mouse embryonic stem cells. However, it showed a low expression in differentiated cells. Therefore, it is not clear how PRC2 is targeted to its genomic sites in other cell types [178]. Also, there is a plethora of chromatinmodifying complexes without DNA binding protein partners to guide them to their action sites $[179,180]$.

Similarly, several large lncRNAs transcribed antisense of protein-coding genes and they can also interact with chromatin modifying complexes and affect the landscape of chromatin [181,182]. For example, the antisense transcript to the Igf2r gene is known as Air and it is required for the allele-specific silencing of several genes in the mouse placenta. The gene functions through direct interaction with the repressive histone methyltransferase G9a $[91,183]$. Similarly, there is a nuclear retained antisense transcript in Kcnq1 gene (Kcnq1ot1). It associates in a tissue-specific manner with the Chromatin complexes G9a and PRC2 and several protein-coding genes within a $1 \mathrm{Mb}$ region in cis will be repressed [31,97] (Figure 5).

\section{LncRNAs with epigenetic regulation}

The mRNA of BCL2 will be negatively regulated by the miR-15a/16-1 group [184]. As an anti-apoptotic gene in cancer, the frequent down-regulation of BCL2 suggests that the failure to induce apoptosis may be reason of melanoma development [185].

LncRNAs play critical roles in epigenetic modulation of chromatin structure by regulating key genes in specific cancerous cells $[186,187]$. Distinct chromatin signatures are associated with lncRNAs encoding genes, and these signatures are demonstrably different in cancer cells, such as in colorectal carcinoma [188]. It found that the expression of elncRNA, instead of plncRNA, was associated with enhanced expression of neighboring protein-coding genes during erythropoiesis [157]. The regulation of lncRNA gene maternally encoded gene 3 by miR-29 and modulating the corresponding chromatin structures in hepatocellular carcinoma cells [189]. DNMT-3A and DNMT-3B are direct targets of miR29. It makes effects indirectly through the latter's influences on DNMT gene expression [190,191]. What is more, over-expressed lncRNAs can be potentially served as a required component of castration-resistance in prostatic tumors with Chromatin remodeling proteins such as Bmi1, Ring2 and Ezh2 [192,193].

The significance of epigenetic regulation of lncRNAs in human melanoma cells is increasing with more evidence $[115,192]$. LncRNAs was widely studied in such

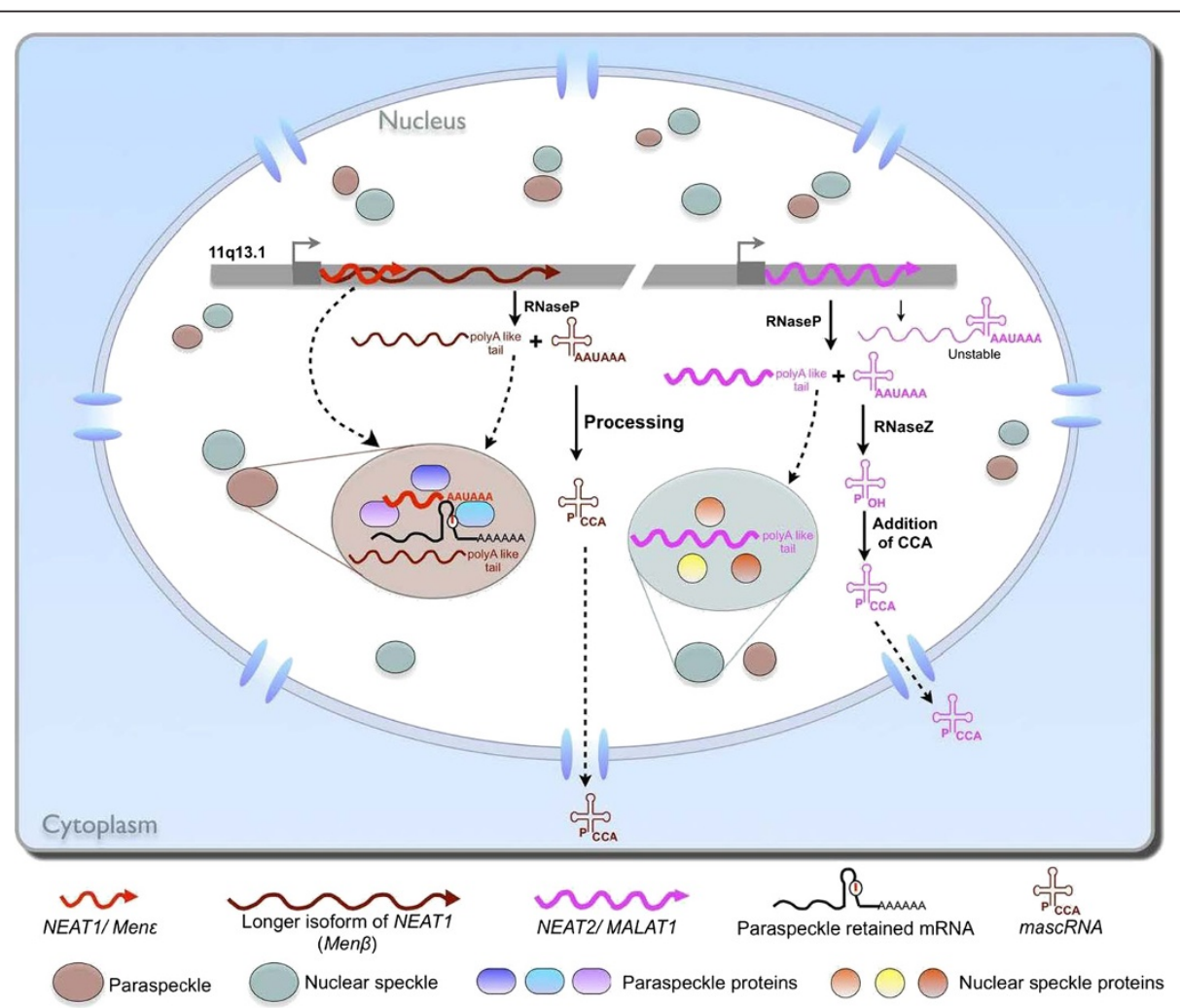

Figure 5 Long non-coding RNAs in nuclear sub-compartments. Human NEAT1 (Mencin mouse) localizes to para-speckles and it is required for para-speckle structural integrity. NEAT2 (MALAT1) localizes to splicing speckles but it is not required for their structural integrity. Nascent Men $\beta$ and MALAT1 transcripts can each be processed by the unusual mechanism of RNase P cleavage to generate the $5^{\prime}$ end of mascRNA (MALAT1- associated small cytoplasmic RNA) and the $3^{\prime}$ end of the mature Men $\beta$ and MALAT1 transcripts, which localize to paraspeckles and splicing speckles, respectively. 
cancers as melanoma, colorectal, head and neck cancer [183]. And LncRNAs clusters were differentially expressed in ovarian cancer cells with varying metastatic potentials. 4,956 lncRNAs have been detected in the microarray, 583 and 578 lncRNAs were upregulated and down-regulated, respectively. Seven of the analyzed lncRNAs (MALAT1, H19, UCA1, CCAT1, LOC645249, LOC100128881, and LOC100292680) confirmed the deregulation found by microarray analysis. LncRNAs play a partial or key role in epithelial ovarian cancer metastasis [194].

\section{Conclusions and future directions}

lncRNAs function make effects in many biological and pathological processes such as stem cell pluripotency, neurogenesis, oncogenesis and etc. In this review, it has focused on the functional roles of lncRNAs in epigenetics and summarized related research progress.

Reasoning, primary ncRNA precursor chains have a high frequency of nonsense codons in their short and highly interrupted 'reading frames'. In addition, they will never be translated into proteins because they are too short. However, they may be associated with proteins that detect nonsense codons within a reading frame.

Thus, distinct forms of chromatin proteins may make effects through protein-protein contacts via the nonsensemediated decay complex proteins. It might be able to organize in genes encoding ncRNA or lncRNAs. Chromatin will also be associated with a variety of other RNA binding proteins. In principle, ncRNAs could exert regulatory effects on the chromatin through their association with any of these proteins. Thus, much more exploratory work is needed in these fields.It was indicated that several ncRNAs are functional and not just 'transcriptional noise' as has been previously speculated. To the early geneticists, a 'gene' was a very abstract entity. It was only considered to reflect the way phenotypes were observed when transmitted between generations. Today, however, it is dispensable to re-evaluate the way for classifying 'gene' and genomic regions of apparently 'gene poor'. It may produce important transcripts. All these will need to be tested with various methods for proving its clinical linkage to diseases.

\footnotetext{
Abbreviations

Anril: Antisense non-coding RNA in the ink4 locus; DNMT: DNA methylation transferase; ElncRNA: Enhancer-associated Long non-coding RNA; FANTOM: Functional Annotation of Mammalian CDNA; GRIM-19: Genes associated with retinoid/interferon-induced mortality-19; ICRs: Imprinting control regions; Kcnq1: Potassium voltage-gated channel subfamily Q member 1; LIT1: Long QT intronic transcript 1; LncRNA: Long non-coding RNA; MBD: Methyl-DNA-binding domain proteins; MBD1: Methyl-DNA-binding domain proteins; MEG3: Maternally expressed 3; mRNA: Messenger RNA; ncRNA: Non-coding RNA; ORF: Open reading frame; PIncRNA: Promoter-associated Long non-coding RNA; PRC: Polycomb repressive complex; PRINS: Psoriasis susceptibility-related RNA Gene Induced by Stress; sncRNA: Small non-coding RNAs; SncRNA: Small non-coding RNAs.
}

\section{Competing interests}

The author's declare that he has no competing interests.
Received: 9 June 2014 Accepted: 6 September 2014

Published: 15 September 2014

\section{References}

1. Frith MC, Bailey TL, Kasukawa T, Mignone F, Kummerfeld SK, Madera M, Sunkara S, Furuno M, Bult CJ, Quackenbush J, Kai C, Kawai J, Carninci P, Hayashizaki Y, Pesole G, Mattick JS: Discrimination of non-protein-coding transcripts from protein-coding mRNA. RNA Biol 2006, 3:40-48.

2. Pang KC, Frith MC, Mattick JS: Rapid evolution of noncoding RNAs: lack of conservation does not mean lack of function. Trends Genet 2006, 22:1-5.

3. Mao YS, Sunwoo H, Zhang B, Spector DL: Direct visualization of the co-transcriptional assembly of a nuclear body by noncoding RNAs. Nat Cell Biol 2011, 13:95-101.

4. Dinger ME, Pang KC, Mercer TR, Mattick JS: Differentiating protein-coding and noncoding RNA: challenges and ambiguities. PLoS Comput Biol 2008, 4:e1000176.

5. Carninci P, Kasukawa T, Katayama S, Gough J, Frith MC, Maeda N, Oyama R, Ravasi T, Lenhard B, Wells C, Kodzius R, Shimokawa K, Bajic VB, Brenner SE, Batalov S, Forrest AR, Zavolan M, Davis MJ, Wilming LG, Aidinis V, Allen JE, Ambesi-Impiombato A, Apweiler R, Aturaliya RN, Bailey TL, Bansal M, Baxter L, Beisel KW, Bersano T, Bono $\mathrm{H}$, et al: The transcriptional landscape of the mammalian genome. Science 2005, 309:1559-1563.

6. Perkel JM: Visiting "noncodarnia". Biotechniques 2013, 54(301):303-304.

7. ENCODE Project Consortium, Birney E, Stamatoyannopoulos JA, Dutta A, Guigó R, Gingeras TR, Margulies EH, Weng Z, Snyder M, Dermitzakis ET, Thurman RE, Kuehn MS, Taylor CM, Neph S, Koch CM, Asthana S, Malhotra A, Adzhubei I, Greenbaum JA, Andrews RM, Flicek P, Boyle PJ, Cao H, Carter NP, Clelland GK, Davis S, Day N, Dhami P, Dillon SC, Dorschner MO, et al: Identification and analysis of functional elements in $1 \%$ of the human genome by the ENCODE pilot project. Nature 2007, 447:799-816.

8. Carninci P, Hayashizaki Y: Noncoding RNA transcription beyond annotated genes. Curr Opin Genet Dev 2007, 17:139-144.

9. Kapranov P, Cheng J, Dike S, Nix DA, Duttagupta R, Willingham AT, Stadler PF, Hertel J, Hackermüller J, Hofacker IL, Bell I, Cheung E, Drenkow J, Dumais E, Patel S, Helt G, Ganesh M, Ghosh S, Piccolboni A, Sementchenko V, Tammana H, Gingeras TR: RNA maps reveal new RNA classes and a possible function for pervasive transcription. Science 2007, 316:1484-1488.

10. Fenoglio C, Ridolfi E, Galimberti D, Scarpini E: An emerging role for long non-coding RNA dysregulation in neurological disorders. Int J Mol Sci 2013, 14:20427-20442.

11. Kaur P, Karolina DS, Sepramaniam S, Armugam A, Jeyaseelan K: Expression profiling of RNA transcripts during neuronal maturation and ischemic injury. PLOS One 2014, 9:e103525.

12. Wu H, Nord AS, Akiyama JA, Shoukry M, Afzal V, Rubin EM, Pennacchio LA, Visel A: Tissue-specific RNA expression marks distant-acting developmental enhancers. PLOS Genet 2014, 10:e1004610.

13. Mattick JS: Non-coding RNAs: the architects of eukaryotic complexity. EMBO Rep 2001, 2:986-991.

14. Pollard KS, Salama SR, King B, Kern AD, Dreszer T, Katzman S, Siepel A, Pedersen JS, Bejerano G, Baertsch R, Rosenbloom KR, Kent J, Haussler D: Forces shaping the fastest evolving regions in the human genome. PLOS Genet 2006, 2:e168.

15. Taft RJ, Pheasant M, Mattick JS: The relationship between non-protein-coding DNA and eukaryotic complexity. Bioessays 2007, 29:288-299.

16. Wilusz JE, Freier SM, Spector DL: $3^{\prime}$ end processing of a long nuclear-retained noncoding RNA yields a tRNA-like cytoplasmic RNA. Cell 2008, 135:919-932.

17. Mercer TR, Qureshi IA, Gokhan S, Dinger ME, Li G, Mattick JS, Mehler MF: Long noncoding RNAs in neuronal-glial fate specification and oligodendrocyte lineage maturation. BMC Neurosci 2010, 11:14.

18. Nollet F, Berx G, Molemans F, van Roy F: Genomic organization of the human beta-catenin gene (CTNNB1). Genomics 1996, 32:413-424.

19. Ponting $C P$, Oliver $P L$, Reik W: Evolution and functions of long noncoding RNAs. Cell 2009, 136:629-641

20. Clamp M, Fry B, Kamal M, Xie X, Cuff J, Lin MF, Kellis M, Lindblad-Toh K, Lander ES: Distinguishing protein-coding and noncoding genes in the human genome. Proc Natl Acad Sci U S A 2007, 104:19428-19433.

21. Liu J, Gough J, Rost B: Distinguishing protein-coding from non-coding RNAs through support vector machines. PLoS Genet 2006, 2:e29.

22. Jia H, Osak M, Bogu GK, Stanton LW, Johnson R, Lipovich L: Genome-wide computational identification and manual annotation of human long noncoding RNA genes. RNA 2010, 16:1478-1487. 
23. Pauli A, Valen E, Lin MF, Garber M, Vastenhouw NL, Levin JZ, Fan L, Sandelin A, Rinn JL, Regev A, Schier AF: Systematic identification of long noncoding RNAs expressed during zebrafish embryogenesis. Genome Res 2012, 22:577-591.

24. Sun L, Zhang Z, Bailey TL, Perkins AC, Tallack MR, Xu Z, Liu H: Prediction of novel long non-coding RNAs based on RNA-Seq data of mouse Klf1 knockout study. BMC Bioinformatics 2012, 13:331.

25. Ng RK, Gurdon JB: Epigenetic inheritance of cell differentiation status. Cell Cycle 2008, 7:1173-1177.

26. Probst AV, Dunleavy $E$, Almouzni G: Epigenetic inheritance during the cell cycle. Nat Rev Mol Cell Biol 2009, 10:192-206.

27. Roloff TC, Nuber UA: Chromatin, epigenetics and stem cells. Eur J Cell Biol 2005, 84:123-135.

28. van Bakel H, Nislow C, Blencowe BJ, Hughes TR: Most "dark matter" transcripts are associated with known genes. PLOS Biol 2010, 8:e1000371.

29. van Bakel $H$, Hughes TR: Establishing legitimacy and function in the new transcriptome. Brief Funct Genomic Proteomic 2009, 8:424-436.

30. Clark MB, Amaral PP, Schlesinger FJ, Dinger ME, Taft RJ, Rinn JL, Ponting CP, Stadler PF, Morris KV, Morillon A, Rozowsky JS, Gerstein MB, Wahlestedt C, Hayashizaki Y, Carninci P, Gingeras TR, Mattick JS: The reality of pervasive transcription. PLOS Biol 2011, 9:e1000625. discussion e1001102.

31. Chen LL, Carmichael GG: Decoding the function of nuclear long non-coding RNAs. Curr Opin Cell Biol 2010, 22:357-364.

32. Dinger ME, Amaral PP, Mercer TR, Pang KC, Bruce SJ, Gardiner BB, Askarian-Amiri ME, Ru K, Soldà G, Simons C, Sunkin SM, Crowe ML, Grimmond SM, Perkins AC, Mattick JS: Long noncoding RNAs in mouse embryonic stem cell pluripotency and differentiation. Genome Res 2008, 18:1433-1445.

33. Loewer S, Cabili MN, Guttman M, Loh YH, Thomas K, Park IH, Garber M, Curran M, Onder T, Agarwal S, Manos PD, Datta S, Lander ES, Schlaeger TM, Daley GQ, Rinn JL: Large intergenic non-coding RNA-RoR modulates reprogramming of human induced pluripotent stem cells. Nat Genet 2010, 42:1113-1117.

34. Fejes-Toth K, Sotirova V, Sachidanandam R, Assaf G, Hannon GJ, Kapranov P, Foissac S, Willingham AT, Duttagupta R, Dumais E, Gingeras TR: Post-transcriptional processing generates a diversity of 5 '-modified long and short RNAs. Nature 2009, 457:1028-1032.

35. Kapranov P, St Laurent G, Raz T, Ozsolak F, Reynolds CP, Sorensen PH, Reaman G, Milos P, Arceci RJ, Thompson JF, Triche TJ: The majority of total nuclear-encoded non-ribosomal RNA in a human cell is 'dark matter' un-annotated RNA. BMC Biol 2010, 8:149.

36. Hannon GJ, Rivas FV, Murchison EP, Steitz JA: The expanding universe of noncoding RNAs. Cold Spring Harb Symp Quant Biol 2006, 71:551-564.

37. Hung $T$, Chang HY: Long noncoding RNA in genome regulation: prospects and mechanisms. RNA Biol 2010, 7:582-585.

38. Pauli A, Rinn JL, Schier AF: Non-coding RNAs as regulators of embryogenesis. Nat Rev Genet 2011, 12:136-149.

39. Valadkhan S, Nilsen TW: Reprogramming of the non-coding transcriptome during brain development. J Biol 2010, 9:5.

40. Mercer TR, Dinger ME, Mattick JS: Long non-coding RNAs: insights into functions. Nat Rev Genet 2009, 10:155-159.

41. Mercer TR, Dinger ME, Mariani J, Kosik KS, Mehler MF, Mattick JS Noncoding RNAs in Long-Term Memory Formation. Neuroscientist 2008, 14:434-445.

42. He Y, Meng XM, Huang C, Wu BM, Zhang L, Lv XW, Li J: Long noncoding RNAs: Novel insights into hepatocelluar carcinoma. Cancer Lett 2014, 344:20-27.

43. Monnier P, Martinet C, Pontis J, Stancheva I, Ait-Si-Ali S, Dandolo L: H19 IncRNA controls gene expression of the Imprinted Gene Network by recruiting MBD1. Proc Natl Acad Sci U S A 2013, 110:20693-20698.

44. Pandey RR, Mondal T, Mohammad F, Enroth S, Redrup L, Komorowski J, Nagano T, Mancini-Dinardo D, Kanduri C: Kcnq1ot1 antisense noncoding RNA mediates lineage-specific transcriptional silencing through chromatin-level regulation. Mol Cell 2008, 32:232-246.

45. Kanduri C, Thakur N, Pandey RR: The length of the transcript encoded from the Kcnq1ot1 antisense promoter determines the degree of silencing. EMBO J 2006, 25:2096-2106.

46. Kanduri C: Kcnq1ot1: a chromatin regulatory RNA. Semin Cell Dev Biol 2011, 22:343-350.

47. Clark MB, Johnston RL, Inostroza-Ponta M, Fox AH, Fortini E, Moscato $P$, Dinger ME, Mattick JS: Genome-wide analysis of long noncoding RNA stability. Genome Res 2012, 22:885-898.
48. Jones MJ, Bogutz $A B$, Lefebvre $L$ : An extended domain of Kcnq1ot1 silencing revealed by an imprinted fluorescent reporter. $\mathrm{Mol} \mathrm{Cell} \mathrm{Biol}$ 2011, 31:2827-2837.

49. Mohammad F, Mondal T, Guseva N, Pandey GK, Kanduri C: Kcnq1ot1 noncoding RNA mediates transcriptional gene silencing by interacting with Dnmt1. Development 2010, 137:2493-2499.

50. Fatica A, Bozzoni l: Long non-coding RNAs: new players in cell differentiation and development. Nat Rev Genet 2014, 15:7-21.

51. Bao J, Wu J, Schuster AS, Hennig GW, Yan W: Expression profiling reveals developmentally regulated IncRNA repertoire in the mouse male germline. Biol Reprod 2013, 89:107.

52. Zhang X, Rice K, Wang Y, Chen W, Zhong Y, Nakayama Y, Zhou Y, Klibanski A: Maternally expressed gene 3 (MEG3) noncoding ribonucleic acid: isoform structure, expression, and functions. Endocrinology 2010, 151:939-947.

53. Miyoshi N, Wagatsuma H, Wakana S, Shiroishi T, Nomura M, Aisaka K, Kohda T, Surani MA, Kaneko-Ishino T, Ishino F: Identification of an imprinted gene, Meg3/Gtl2 and its human homologue MEG3, first mapped on mouse distal chromosome 12 and human chromosome 14q. Genes Cells 2000, 5:211-220.

54. Zhang X, Zhou Y, Mehta KR, Danila DC, Scolavino S, Johnson SR, Klibanski A: A pituitary-derived MEG3 isoform functions as a growth suppressor in tumor cells. J Clin Endocrinol Metab 2003, 88:5119-5126.

55. Zhang X, Gejman R, Mahta A, Zhong Y, Rice KA, Zhou Y, Cheunsuchon P, Louis DN, Klibanski A: Maternally expressed gene 3, an imprinted noncoding RNA gene, is associated with meningioma pathogenesis and progression. Cancer Res 2010, 70:2350-2358.

56. Jia LF, Wei SB, Gan YH, Guo Y, Gong K, Mitchelson K, Cheng J, Yu GY: Expression, Regulation and Roles of MiR-26a and MEG3 in Tongue Squamous Cell Carcinoma. Int J Cancer 2014, 135:2282-2293.

57. Reeves MB, Davies AA, McSharry BP, Wilkinson GW, Sinclair JH: Complex I binding by a virally encoded RNA regulates mitochondria-induced cell death. Science 2007, 316:1345-1348.

58. Moon YM, Lee J, Lee SY, Her YM, Ryu JG, Kim EK, Son HJ, Kwok SK, Ju JH, Yang CW, Park SH, Kim HY, Cho ML: Gene-associated retinoid-interferoninduced mortality 19 (GRIM-19) attenuates autoimmune arthritis by regulation of Th17 and Treg cells. Arthritis Rheum 2014, 66:569-578.

59. Zhao J, Sinclair J, Houghton J, Bolton E, Bradley A, Lever A: Cytomegalovirus beta2.7 RNA transcript protects endothelial cells against apoptosis during ischemia/reperfusion injury. J Heart Lung Transplant 2010, 29:342-345.

60. Yu HC, Bai L, Yue SQ, Wang DS, Wang L, Han H, Dou KF: Notch signal protects non-parenchymal cells from ischemia/reperfusion injury in vitro by repressing ROS. Ann Hepatol 2013, 12:815-821.

61. Gutschner T, Diederichs S: The hallmarks of cancer: a long non-coding RNA point of view. RNA Biol 2012, 9:703-719.

62. Sonkoly E, Bata-Csorgo Z, Pivarcsi A, Polyanka H, Kenderessy-Szabo A, Molnar G, Szentpali K, Bari L, Megyeri K, Mandi Y, Dobozy A, Kemeny L, Szell M: Identification and characterization of a novel, psoriasis susceptibility-related noncoding RNA gene. PRINS J Biol Chem 2005, 280:24159-24167.

63. Szegedi K, Sonkoly E, Nagy N, Németh IB, Bata-Csörgo Z, Kemény L, Dobozy A, Széll M: The anti-apoptotic protein G1P3 is overexpressed in psoriasis and regulated by the non-coding RNA. PRINS Exp Dermato/ 2010, 19:269-278.

64. Bayley JP, van Minderhout I, Hogendoorn PC, Cornelisse CJ, van der Wal A, Prins FA, Teppema L, Dahan A, Devilee P, Taschner PE: Sdhd and SDHD/H19 knockout mice do not develop paraganglioma or pheochromocytoma. PLoS One 2009, 4:e7987.

65. Swindell WR1, Johnston A, Xing X, Voorhees JJ, Elder JT, Gudjonsson JE: Modulation of epidermal transcription circuits in psoriasis: new links between inflammation and hyperproliferation. PLOS One 2013, 8:e79253.

66. Prensner JR, lyer MK, Balbin OA, Dhanasekaran SM, Cao Q, Brenner JC, Laxman B, Asangani IA, Grasso CS, Kominsky HD, Cao X, Jing X, Wang X, Siddiqui J, Wei JT, Robinson D, lyer HK, Palanisamy N, Maher CA, Chinnaiyan AM: Transcriptome sequencing across a prostate cancer cohort identifies PCAT-1, an unannotated lincRNA implicated in disease progression. Nat Biotechnol 2011, 29:742-749.

67. Burd CE, Jeck WR, Liu Y, Sanoff HK, Wang Z, Sharpless NE: Expression of linear and novel circular forms of an INK4/ARF-associated non-coding RNA correlates with atherosclerosis risk. PLOS Genet 2010, 6:e1001233.

68. Kotake Y, Nakagawa T, Kitagawa K, Suzuki S, Liu N, Kitagawa M, Xiong Y: Long non-coding RNA ANRIL is required for the PRC2 recruitment to and silencing of p15 (INK4B) tumor suppressor gene. Oncogene 2011, 30:1956-1962 
69. Popov N, Gil J: Epigenetic regulation of the INK4b-ARF-INK4a locus: in sickness and in health. Epigenetics 2010, 5:685-690.

70. White NM, Cabanski CR, Silva-Fisher JM, Dang HX, Govindan R, Maher CA: Transcriptome sequencing reveals altered long intergenic non-coding RNAs in lung cancer. Genome Biol 2014, 15:429.

71. Gupta RA, Shah N, Wang KC, Kim J, Horlings HM, Wong DJ, Tsai MC, Hung T, Argani P, Rinn JL, Wang Y, Brzoska P, Kong B, Li R, West RB, van de Vijver MJ, Sukumar $\mathrm{S}$, Chang HY: Long non-coding RNA HOTAIR reprograms chromatin state to promote cancer metastasis. Nature 2010, 464:1071-1076.

72. Yang Z, Zhou L, Wu LM, Lai MC, Xie HY, Zhang F, Zheng SS: Overexpression of long non-coding RNA HOTAIR predicts tumor recurrence in hepatocellular carcinoma patients following liver transplantation. Ann Surg Oncol 2011, 18:1243-1250.

73. Kogo R, Shimamura T, Mimori K, Kawahara K, Imoto S, Sudo T, Tanaka F, Shibata K, Suzuki A, Komune S, Miyano S, Mori M: Long noncoding RNA HOTAIR regulates polycomb-dependent chromatin modification and is associated with poor prognosis in colorectal cancers. Cancer Res 2011, 71:6320-6326.

74. Niinuma T, Suzuki H, Nojima M, Nosho K, Yamamoto H, Takamaru H, Yamamoto E, Maruyama R, Nobuoka T, Miyazaki Y, Nishida T, Bamba T, Kanda T, Ajioka Y, Taguchi T, Okahara S, Takahashi H, Nishida Y, Hosokawa M, Hasegawa T, Tokino T, Hirata K, Imai K, Toyota M, Shinomura Y: Upregulation of miR-196a and HOTAIR drive malignant character in gastrointestinal stromal tumors. Cancer Res 2012, 72:1126-1136.

75. Kim K, Jutooru I, Chadalapaka G, Johnson G, Frank J, Burghardt R, Kim S, Safe $\mathrm{S}$ : HOTAIR is a negative prognostic factor and exhibits pro-oncogenic activity in pancreatic cancer. Oncogene 2013, 32:1616-1625.

76. Rothhammer T, Bosserhoff AK: Epigenetic events in malignant melanoma. Pigment Cell Res 2007, 20:92-111.

77. Xia J, Zhang X, Yuan D, Chen L, Webster J, Fang AC: Gene Prioritization of Resistant Rice Gene against Xanthomas oryzae pv. oryzae by Using Text Mining Technologies. Biomed Res Int 2013, 2013:853043.

78. Mattick JS, Mehler MF: RNA editing, DNA recoding and the evolution of human cognition. Trends Neurosci 2008, 31:227-233

79. Mehler MF, Mattick JS: Noncoding RNAs and RNA editing in brain development, functional diversification, and neurological disease. Physiol Rev 2007, 87:799-823.

80. Hertz L: Bioenergetics of cerebral ischemia: a cellular perspective. Neuropharmacology 2008, 55:289-309.

81. Qureshi IA, Mattick JS, Mehler MF: Long non-coding RNAs in nervous system function and disease. Brain Res 2010, 1338:20-35.

82. Qureshi IA, Mehler MF: Emerging roles of non-coding RNAs in brain evolution, development, plasticity and disease. Nat Rev Neurosci 2012, 13:528-541.

83. Lin M, Pedrosa E, Shah A, Hrabovsky A, Magbool S, Zheng D, Lachman HM: RNA-Seq of human neurons derived from iPS cells reveals candidate long non-coding RNAs involved in neurogenesis and neuropsychiatric disorders. PloS One 2011, 6:e23356.

84. Ng SY, Johnson R, Stanton LW: Human long non-coding RNAs promote pluripotency and neuronal differentiation by association with chromatin modifiers and transcription factors. EMBO J 2012, 31:522-533.

85. Sobocki T, Sobocka MB, Babinska A, Ehrlich YH, Banerjee P, Kornecki E: Genomic structure, organization and promoter analysis of the human F11R/F11 receptor/junctional adhesion molecule-1/JAM-A. Gene 2006, 366:128-144.

86. Riccardo S, Tortoriello G, Giordano E, Turano M, Furia M: The coding/non-coding overlapping architecture of the gene encoding the Drosophila pseudouridine synthase. BMC Mol Biol 2007, 8:15.

87. Qureshi IA, Mehler MF: The emerging role of epigenetics in stroke: II. RNA regulatory circuitry. Arch Neurol 2010, 67:1435-1441.

88. Latos PA, Pauler FM, Koerner MV, Şenergin HB, Hudson QJ, Stocsits RR, Allhoff W, Stricker SH, Klement RM, Warczok KE, Aumayr K, Pasierbek P, Barlow DP: Airn transcriptional overlap, but not its IncRNA products, induces imprinted Igf2r silencing. Science 2012, 338:1469-1472.

89. He S, Liu S, Zhu H: The sequence, structure and evolutionary features of HOTAIR in mammals. BMC Evol Biol 2011, 11:102.

90. Tang L, Zhang W, Su B, Yu B: Long noncoding RNA HOTAIR is associated with motility, invasion, and metastatic potential of metastatic melanoma. Biomed Res Int 2013, 2013:251098.

91. Sleutels F, Zwart R, Barlow DP: The non-coding Air RNA is required for silencing autosomal imprinted genes. Nature 2002, 415:810-813.
92. Brockdorff N, Ashworth A, Kay GF, Cooper P, Smith S, McCabe VM, Norris DP, Penny GD, Patel D, Rastan S: Conservation of position and exclusive expression of mouse Xist from the inactive X chromosome. Nature 1991, 351:329-331.

93. Penny GD, Kay GF, Sheardown SA, Rastan S, Brockdorff N: Requirement for Xist in X chromosome inactivation. Nature 1996, 379:131-137.

94. Brockdorff N, Ashworth A, Kay GF, McCabe VM, Norris DP, Cooper PJ, Swift S, Rastan S: The product of the mouse Xist gene is a $15 \mathrm{~kb}$ inactive X-specific transcript containing no conserved ORF and located in the nucleus. Cell 1992, 71:515-526.

95. Rinn JL, Kertesz M, Wang JK, Squazzo SL, Xu X, Brugmann SA, Goodnough LH Helms JA, Farnham PJ, Segal E, Chang HY: Functional demarcation of active and silent chromatin domains in human HOX loci by noncoding RNAs. Cell 2007, 129:1311-1323.

96. Mancini-Dinardo D, Steele SJ, Levorse JM, Ingram RS, Tilghman SM: Elongation of the Kcnq1ot1 transcript is required for genomic imprinting of neighboring genes. Genes Dev 2006, 20:1268-1282.

97. Liang M, Li W, Tian H, Hu T, Wang 3, Lin Y, Li Y, Huang H, Sun F: Sequential expression of long noncoding RNA as mRNA gene expression in specific stages of mouse spermatogenesis. Sci Rep 2014, 4:5966.

98. Tani H, Mizutani R, Salam KA, Tano K, ljiri K, Wakamatsu A, Isogai T, Suzuki Y, Akimitsu N: Genome-wide determination of RNA stability reveals hundreds of short-lived noncoding transcripts in mammals. Genome Res 2012, 22:947-956.

99. Mata J: Genome-wide mapping of polyadenylation sites in fission yeast reveals widespread alternative polyadenylation. RNA Biol 2013, 10:1407-1414.

100. Russell PJ: iGenetics. 3rd ed. San Francisco: Pearson Benjamin Cummings. Expert Opin Biol 2010, 12:217-230.

101. Saffhill R, Itzhaki RF: Accessibility of chromatin to DNA polymerase I and location of the F1 histone. Nucleic Acids Res 1975, 2:113-119.

102. Bustin M: Arrangement of histones in chromatin. Nat New Biol 1973, 245:207-209.

103. Prioleau MN, Huet J, Sentenac A, Méchali M: Competition between chromatin and transcription complex assembly regulates gene expression during early development. Cell 1994, 77:439-449.

104. Voss TC, John S, Hager GL: Single-cell analysis of glucocorticoid receptor action reveals that stochastic post-chromatin association mechanisms regulate ligand-specific transcription. Mol Endocrinol 2006, 20:2641-2655.

105. Koike K, Kasamatsu A, lyoda M, Saito Y, Kouzu Y, Koike H, Sakamoto Y, Ogawara K, Tanzawa H, Uzawa K: High prevalence of epigenetic inactivation of the human four and a half LIM domains 1 gene in human oral cancer. Int J Oncol 2013, 42:141-150.

106. Chang CP, Bruneau BG: Epigenetics and cardiovascular development. Annu Rev Physiol 2012, 74:41-68.

107. Wutz A: Epigenetic regulation of stem cells: the role of chromatin in cell differentiation. Adv Exp Med Biol 2013, 786:307-328.

108. Kouzarides T: Chromatin modifications and their function. Cell 2007, 128:693-705.

109. Shiio Y, Eisenman RN: Histone sumoylation is associated with transcriptional repression. Proc Natl Acad Sci U S A 2003, 100:13225-13230.

110. Yang XJ: Multisite protein modification and intramolecular signaling. Oncogene 2005, 24:1653-1662.

111. Shilatifard A: Chromatin modifications by methylation and ubiquitination: implications in the regulation of gene expression. Annu Rev Biochem 2006, 75:243-269.

112. Xie W, Ames RS, Li H: A cell-based high-throughput screening assay to measure cellular histone $\mathrm{h} 3$ lys 27 trimethylation with a modified dissociation-enhanced lanthanide fluorescent immunoassay. J Biomol Screen 2012, 17:99-107.

113. Liu D, Xu B, Chen S, Yang Y, Zhang X, Liu J, Lu K, Zhang L, Liu C, Zhao Y, Jiang H, Liu N, Chen M: Long non-coding RNAs and prostate cancer. J Nanosci Nanotechnol 2013, 13:3186-3194.

114. Gibb EA, Brown CJ, Lam WL: The functional role of long non-coding RNA in human carcinomas. Mol Cancer 2011, 10:38-55.

115. Khaitan D, Dinger ME, Mazar J, Crawford J, Smith MA, Mattick JS, Perera RJ: The melanoma-upregulated long noncoding RNA SPRY4-IT1 modulates apoptosis and invasion. Cancer Res 2011, 71:3852-3862.

116. Mazar J, DeBlasio D, Govindarajan SS, Zhang S, Perera RJ: Epigenetic regulation of microRNA-375 and its role in melanoma development in humans. FEBS Lett 2011, 585:2467-2476.

117. Dudziec E, Goepel JR, Catto JW: Global epigenetic profiling in bladder cancer. Epigenomics 2011, 3:35-45.

118. Guil S, Esteller M: DNA methylomes, histone codes and miRNAs: tying it all together. Int J Biochem Cell Biol 2009, 41:87-95. 
119. Garding A, Bhattacharya N, Claus R, Ruppel M, Tschuch C, Filarsky K, Idler I, Zucknick M, Caudron-Herger M, Oakes C, Fleig V, Keklikoglou I, Allegra D, Serra L, Thakurela S, Tiwari V, Weichenhan D, Benner A, Radlwimmer B, Zentgraf H, Wiemann S, Rippe K, Plass C, Döhner H, Lichter P, Stilgenbauer S, Mertens D: Epigenetic upregulation of IncRNAs at $13 q 14.3$ in leukemia is linked to the In Cis downregulation of a gene cluster that targets NF-kB. PLoS Genet 2013, 9:e1003373.

120. Mazar J, Khaitan D, DeBlasio D, Zhong C, Govindarajan SS, Kopanathi S, Zhang S, Ray A, Perera RJ: Epigenetic regulation of microRNA genes and the role of miR-34b in cell invasion and motility in human melanoma. PLoS One 2011, 6:e24922.

121. Chen X, He D, Dong XD, Dong F, Wang J, Wang L, Tang J, Hu DN, Yan D, Tu L: MicroRNA-124a is epigenetically regulated and acts as a tumor suppressor by controlling multiple targets in uveal melanoma. Invest Ophthalmol Vis Sci 2013, 54:2248-2256.

122. Kuphal S, Martyn AC, Pedley J, Crowther LM, Bonazzi VF, Parsons PG, Bosserhoff AK, Hayward NK, Boyle GM: H-cadherin expression reduces invasion of malignant melanoma. Pigment Cell Melanoma Res 2009, 22:296-306.

123. Lopez-Serra P1, Esteller M: DNA methylation-associated silencing of tumor-suppressor microRNAs in cancer. Oncogene 2012, 31:1609-1622.

124. Hassel JC, Sucker A, Edler L, Kurzen H, Moll I, Stresemann C, Spieth K, Mauch C, Rass K, Dummer R, Schadendorf D: MGMT gene promoter methylation correlates with tolerance of temozolomide treatment in melanoma but not with clinical outcome. Br J Cancer 2010, 103:820-826.

125. Lujambio A, Esteller M: CpG island hypermethylation of tumor suppressor microRNAs in human cancer. Cell Cycle 2007, 6:1455-1459.

126. Csankovszki G, Nagy A, Jaenisch R: Synergism of Xist RNA, DNA methylation, and histone hypoacetylation in maintaining $X$ chromosome inactivation. J Cell Biol 2001, 153:773-784.

127. Brose RD, Shin G, McGuinness MC, Schneidereith T, Purvis S, Dong GX, Keefer J, Spencer F, Smith KD: Activation of the stress proteome as a mechanism for small molecule therapeutics. Hum Mol Genet 2012, 21:4237-4252

128. Liu N, Parisien M, Dai Q, Zheng G, He C, Pan T: Probing N6-methyladenosine RNA modification status at single nucleotide resolution in mRNA and long noncoding RNA. RNA 2013, 19:1848-1856.

129. Hsieh CL: In vivo activity of murine de novo methyltransferases, Dnmt3a and Dnmt3b. Mol Cell Biol 1999, 19:8211-8218.

130. Maquat LE: Nonsense-mediated mRNA decay: splicing, translation and mRNP dynamics. Nat Rev Mol Cell Biol 2004, 5:89-99.

131. Lehmann U, Hasemeier B, Christgen M, Müller M, Römermann D, Länger F, Kreipe $\mathrm{H}$ : Epigenetic inactivation of microRNA gene hsa-mir-9-1 in human breast cancer. J Pathol 2008, 214:17-24.

132. Grady WM, Parkin RK, Mitchell PS, Lee JH, Kim YH, Tsuchiya KD, Washington MK, Paraskeva C, Willson JK, Kaz AM, Kroh EM, Allen A, Fritz BR, Markowitz SD, Tewari M: Epigenetic silencing of the intronic microRNA hsa-miR-342 and its host gene EVL in colorectal cancer. Oncogene 2008, 27:3880-3888.

133. Casadio V, Molinari C, Calistri D, Tebaldi M, Gunelli R, Serra L, Falcini F, Zingaretti C, Silvestrini R, Amadori D, Zoli W: DNA Methylation profiles as predictors of recurrence in non muscle invasive bladder cancer: an MS-MLPA approach. J Exp Clin Cancer Res 2013, 32:94.

134. Jung EJ, Kim IS, Lee EY, Kang JE, Lee SM, Kim DC, Kim JY, Park ST: Comparison of methylation profiling in cancerous and their corresponding normal tissues from korean patients with breast cancer. Ann Lab Med 2013, 33:431-440.

135. Iscovich J, Ackerman C, Andreev H, Pe'er J, Steinitz R: An epidemiological study of posterior uveal melanoma in Israel, 1961-1989. Int J Cancer 1995, 61:291-295.

136. Jeffery L, Nakielny S: Components of the DNA methylation system of chromatin control are RNA-binding proteins. J Biol Chem 2004, 279:49479-49487.

137. Robertson KD: DNA methylation and human disease. Nat Rev Genet 2005, 6:597-610.

138. Bestor TH: The DNA, methyltransferases of mammals. Hum Mol Genet 2000, 9:2395-2402

139. Bird A: DNA methylation patterns and epigenetic memory. Genes Dev 2002, 16:6-21.

140. Okano M, Bell DW, Haber DA, Li E: DNA methyltransferases Dnmt3a and Dnmt3b are essential for de novo methylation and mammalian development. Cell 1999, 99:247-257.
141. Groth A, Rocha W, Verreault A, Almouzni G: Chromatin challenges during DNA replication and repair. Cell 2007, 128:721-733.

142. Mani S, Szymańska K, Cuenin C, Zaridze D, Balassiano K, Lima SC, Matos E, Daudt A, Koifman S, Filho WW, Menezes AM, Curado MP, Ferro G, Vaissière T, Sylla BS, Tommasino M, Pinto LF, Boffetta P, Hainaut P, Brennan P, Herceg Z: DNA methylation changes associated with risk factors in tumors of the upper aerodigestive tract. Epigenetics 2012, 7:270-277.

143. da Rocha ST, Boeva V, Escamilla-Del-Arenal M, Ancelin K, Granier C, Matias NR, Sanulli S, Chow J, Schulz E, Picard C, Kaneko S, Helin K, Reinberg D, Stewart AF, Wutz A, Margueron R, Heard E: Jarid2 Is Implicated in the Initial Xist-Induced Targeting of PRC2 to the Inactive X Chromosome. Mol Cell 2014, 53:301-316.

144. Rossetto CC, Tarrant-Elorza M, Pari GS: Cis and trans acting factors involved in human cytomegalovirus experimental and natural latent infection of CD14 (+) monocytes and CD34 (+) cells. PLOS Pathog 2013, 9:e1003366.

145. Berghoff EG, Clark MF, Chen S, Cajigas I, Leib DE, Kohtz JD: Evf2 (Dlx6as) IncRNA regulates ultraconserved enhancer methylation and the differential transcriptional control of adjacent genes. Development 2013, 140:4407-4416.

146. Beckedorff FC, Ayupe AC, Crocci-Souza R, Amaral MS, Nakaya HI, Soltys DT, Menck CF, Reis EM, Verjovski-Almeida S: The intronic long noncoding RNA ANRASSF1 recruits PRC2 to the RASSF1A promoter, reducing the expression of RASSF1A and increasing cell proliferation. PLOS Genet 2013, 9:e1003705.

147. Liu Q, Huang J, Zhou N, Zhang Z, Zhang A, Lu Z, Wu F, Mo YY: LncRNA loc285194 is a p53-regulated tumor suppressor. Nucleic Acids Res 2013 41:4976-4987.

148. Yang F, Huo XS, Yuan SX, Zhang L, Zhou WP, Wang F, Sun SH: Repression of the long noncoding RNA-LET by histone deacetylase 3 contributes to hypoxia-mediated metastasis. Mol Cell 2013, 49:1083-1096.

149. Yang F, Zhang L, Huo XS, Yuan JH, Xu D, Yuan SX, Zhu N, Zhou WP, Yang GS, Wang $Y Z$, Shang JL, Gao CF, Zhang FR, Wang F, Sun SH: Long noncoding RNA high expression in hepatocellular carcinoma facilitates tumor growth through enhancer of zeste homolog 2 in humans. Hepatology 2011, 54:1679-1689.

150. Li Z, Chao TC, Chang KY, Lin N, Patil VS, Shimizu C, Head SR, Burns JC, Rana TM: The long noncoding RNA THRIL regulates TNFalpha expression through its interaction with hnRNPL. Proc Natl Acad Sci U S A 2014, 111:1002-1007.

151. Carpenter S, Aiello D, Atianand MK, Ricci EP, Gandhi P, Hall LL, Byron M, Monks B, Henry-Bezy M, Lawrence JB, O'Neill LA, Moore MJ, Caffrey DR, Fitzgerald KA: A long noncoding RNA mediates both activation and repression of immune response genes. Science 2013, 341:789-792.

152. Kawahara Y, Zinshteyn B, Chendrimada TP, Shiekhattar R, Nishikura K: RNA editing of the microRNA-151 precursor blocks cleavage by the Dicer-TRBP complex. EMBO Rep 2007, 8:763-769.

153. Kim JB, Piao CS, Lee KW, Han PL, Ahn Jl, Lee YS, Lee JK: Delayed genomic responses to transient middle cerebral artery occlusion in the rat. J Neurochem 2004, 89:1271-1282.

154. Shimamura N, Matchett G, Yatsushige H, Calvert JW, Ohkuma H, Zhang J: Inhibition of integrin alphavbeta3 ameliorates focal cerebral ischemic damage in the rat middle cerebral artery occlusion model. Stroke 2006, 37:1902-1909.

155. Shani V, Bromberg Y, Sperling O, Zoref-Shani E: Involvement of Src tyrosine kinases (SFKs) and of focal adhesion kinase (FAK) in the injurious mechanism in rat primary neuronal cultures exposed to chemical ischemia. J Mol Neurosci 2009, 37:50-59.

156. Qiao YQ, Huang ML, Xu AT, Zhao D, Ran ZH, Shen J: LncRNA DQ786243 affects Treg related CREB and Foxp3 expression in Crohn's disease. J Biomed Sci 2013, 20:87.

157. Marques AC, Hughes J, Graham B, Kowalczyk MS, Higgs DR, Ponting CP: Chromatin signatures at transcriptional start sites separate two equally populated yet distinct classes of intergenic long noncoding RNAs. Genome Biol 2013, 14:R131.

158. Alvarez-Dominguez JR, Hu W, Yuan B, Shi J, Park SS, Gromatzky AA, van Oudenaarden A, Lodish HF: Global discovery of erythroid long non-coding RNAs reveals novel regulators of red cell maturation. Blood 2014, 123:570-581.

159. Gumireddy K, Li A, Yan J, Setoyama T, Johannes GJ, Orom UA, Tchou J, Liu Q, Zhang L, Speicher DW, Calin GA, Huang Q: Identification of a long non-coding RNA-associated RNP complex regulating metastasis at the translational step. EMBO J 2013, 32:2672-2684. 
160. Hong CP, Park J, Roh TY: Epigenetic regulation in cell reprogramming revealed by genome-wide analysis. Epigenomics 2011, 3:73-81.

161. Ishibashi M, Kogo R, Shibata K, Sawada G, Takahashi Y, Kurashige J, Akiyoshi S, Sasaki S, Iwaya T, Sudo T, Sugimachi K, Mimori K, Wakabayashi G, Mori M: Clinical significance of the expression of long non-coding RNA HOTAIR in primary hepatocellular carcinoma. Oncol Rep 2013, 29:946-950.

162. Yu W, Gius D, Onyango P, Muldoon-Jacobs K, Karp J, Feinberg AP, Cui H: Epigenetic silencing of tumour suppressor gene $p 15$ by its antisense RNA. Nature 2008, 451:202-206.

163. Hatta Y, Hirama T, Miller CW, Yamada Y, Tomonaga M, Koeffler HP: Homozygous deletions of the p15 (MTS2) and p16 (CDKN2/MTS1) genes in adult T-cell leukemia. Blood 1995, 85:2699-2704.

164. Otsuki T, Jaffe ES, Wellmann A, Kumar S, Condron KS, Raffeld M: Absence of p18 mutations or deletions in lymphoid malignancies. Leukemia 1996, 10:356-360.

165. Martinez-Delgado B, Robledo M, Arranz E, Osorio A, García MJ, Echezarreta G, Rivas C, Benitez J: Hypermethylation of p15/ink4b/MTS2 gene is differentially implicated among non-Hodgkin's lymphomas. Leukemia 1998, 12:937-941.

166. Maloney KW, McGavran L, Odom LF, Hunger SP: Different patterns of homozygous p16INK4A and p15INK4B deletions in childhood acute lymphoblastic leukemias containing distinct E2A translocations. Leukemia 1998, 12:1417-1421.

167. Zhang J, Zhang P, Wang L, Piao HL, Ma L: Long non-coding RNA HOTAIR in carcinogenesis and metastasis. Acta Biochim Biophys Sin (Shanghai) 2014, 46:1-5.

168. Meisel L, Lam E: Switching of gene expression: analysis of the factors that spatially and temporally regulate plant gene expression. Genet Eng (N Y) 1997, 19:183-199.

169. Volpe T, Schramke V, Hamilton GL, White SA, Teng G, Martienssen RA, Allshire RC: RNA interference is required for normal centromere function in fission yeast. Chromosome Res 2003, 11:137-146.

170. Liu F, Marquardt S, Lister C, Swiezewski S, Dean C: Targeted 3' processing of antisense transcripts triggers Arabidopsis FLC chromatin silencing. Science 2010, 327:94-97.

171. Ohhata T, Hoki Y, Sasaki H, Sado T: Crucial role of antisense transcription across the Xist promoter in Tsix-mediated Xist chromatin modification. Development 2008, 135:227-235.

172. Kanduri C: Functional insights into long antisense noncoding RNA Kcnq1ot1 mediated bidirectional silencing. RNA Biol 2008, 5:208-211.

173. Bernstein BE, Meissner A, Lander ES: The mammalian epigenome. Cell 2007, 128:669-681.

174. Masri S, Sassone-Corsi P: Sirtuins and the circadian clock: Bridging chromatin and metabolism. Sci Signal 2014, 7:re6.

175. Aravind L, lyer LM: The SWIRM domain: a conserved module found in chromosomal proteins points to novel chromatin-modifying activities. Genome Biol 2002, 3:RESEARCH0039.

176. Lee KK, Prochasson P, Florens L, Swanson SK, Washburn MP, Workman JL: Proteomic analysis of chromatin-modifying complexes in Saccharomyces cerevisiae identifies novel subunits. Biochem Soc Trans 2004, 32:899-903.

177. Khalil AM, Rinn JL: RNA-protein interactions in human health and disease. Semin Cell Dev Biol 2011, 22:359-365.

178. Heinlein CA, Chang C: Androgen receptor (AR) coregulators: an overview. Endocr Rev 2002, 23:175-200.

179. Hassan AH, Neely KE, Vignali M, Reese JC, Workman JL: Promoter targeting of chromatin-modifying complexes. Front Biosci 2001, 6:D1054-D1064.

180. Bingham AJ, Ooi L, Kozera L, White E, Wood IC: The repressor element 1-silencing transcription factor regulates heart-specific gene expression using multiple chromatin-modifying complexes. Mol Cell Biol 2007, 27:4082-4092.

181. Marchese FP, Huarte M: Long non-coding RNAs and chromatin modifiers: their place in the epigenetic code. Epigenetics 2014, 9:21-26.

182. Boerner S, McGinnis KM: Computational identification and functional predictions of long noncoding RNA in Zea mays. PLOS One 2012, 7:e43047.

183. Nagano T, Mitchell JA, Sanz LA, Pauler FM, Ferguson-Smith AC, Feil R, Fraser P. The Air noncoding RNA epigenetically silences transcription by targeting G9a to chromatin. Science 2008, 322:1717-1720.

184. Xia L, Zhang D, Du R, Pan Y, Zhao L, Sun S, Hong L, Liu J, Fan D: miR-15b and miR-16 modulate multidrug resistance by targeting BCL2 in human gastric cancer cells. Int J Cancer 2008, 123:372-379.
185. Yan D, Dong XD, Chen X, Yao S, Wang L, Wang J, Wang C, Hu DN, Qu J, Tu L: Role of microRNA-182 in posterior uveal melanoma: regulation of tumor development through MITF, BCL2 and cyclin D2. PLoS One 2012, 7:e40967.

186. Huo JS, Zambidis ET: Pivots of pluripotency: the roles of non-coding RNA in regulating embryonic and induced pluripotent stem cells. Biochim Biophys Acta 2013, 1830:2385-2394

187. Hawkins $\mathrm{PG}$, Morris KV: Transcriptional regulation of Oct4 by a long non-coding RNA antisense to Oct4-pseudogene 5. Transcription 2010, 1:165-175.

188. Suzuki H, Takatsuka S, Akashi H, Yamamoto E, Nojima M, Maruyama R, Kai M, Yamano HO, Sasaki Y, Tokino T, Shinomura Y, Imai K, Toyota M: Genome-wide profiling of chromatin signatures reveals epigenetic regulation of MicroRNA genes in colorectal cancer. Cancer Res 2011, 71:5646-5658

189. Braconi C, Kogure T, Valeri N, Huang N, Nuovo G, Costinean S, Negrini M, Miotto E, Croce CM, Patel T: microRNA-29 can regulate expression of the long non-coding RNA gene MEG3 in hepatocellular cancer. Oncogene 2011, 30:4750-4756.

190. Selvakumar T, Gijidoda A, Hovde SL, Henry RW: Regulation of human RNA polymerase III transcription by DNMT1 and DNMT3a DNA methyltransferases. J Biol Chem 2012, 287:7039-7050.

191. Bönsch D, Lenz B, Fiszer R, Frieling H, Kornhuber J, Bleich S: Lowered DNA methyltransferase (DNMT-3b) mRNA expression is associated with genomic DNA hypermethylation in patients with chronic alcoholism. J Neural Transm 2006, 113:1299-1304.

192. So AY, Jung JW, Lee S, Kim HS, Kang KS: DNA methyltransferase controls stem cell aging by regulating BMI1 and EZH2 through microRNAs. PLOS One 2011, 6:e19503.

193. Yang L, Lin C, Jin C, Yang JC, Tanasa B, Li W, Merkurjev D, Ohgi KA, Meng D, Zhang J, Evans CP, Rosenfeld MG: IncRNA-dependent mechanisms of androgen-receptor-regulated gene activation programs. Nature 2013, 500:598-602.

194. Liu SP, Yang JX, Cao DY, Shen K: Identification of differentially expressed long non-coding RNAs in human ovarian cancer cells with different metastatic potentials. Cancer Biol Med 2013, 10:138-141.

doi:10.1186/1480-9222-16-11

Cite this article as: Cao: The functional role of long non-coding RNAs and epigenetics. Biological Procedures Online 2014 16:11.

\section{Submit your next manuscript to BioMed Central and take full advantage of:}

- Convenient online submission

- Thorough peer review

- No space constraints or color figure charges

- Immediate publication on acceptance

- Inclusion in PubMed, CAS, Scopus and Google Scholar

- Research which is freely available for redistribution 